\title{
Pandanaceae of the island of Yapen, Papua (West New Guinea), Indonesia, with their nomenclature and notes on the rediscovery of Sararanga sinuosa, and several new species and records
}

\author{
A.P. Keim ${ }^{1}$
}

\author{
Key words \\ Freycinetia \\ New Guinea \\ Pandanaceae \\ Pandanus \\ Papua \\ Sararanga \\ Yapen
}

\begin{abstract}
Eleven species of Pandanaceae are recorded for Yapen Island, Papua, Indonesia, seven of Pandanus, three of Freycinetia, including two new ones, and the rediscovery of Sararanga sinuosa. Except for the latter all others are new records for the island.
\end{abstract}

Published on 30 October 2009

\section{INTRODUCTION}

Yapen is one of the islands in the Cenderawasih (Geelvink) Bay in the Indonesian Province of Papua, West New Guinea. The island is about $2400 \mathrm{~km}^{2}$, of which approximately $3 / 4$ is still covered with lavish lowland tropical rainforest, and an area of about $780 \mathrm{~km}^{2}$ is protected as the Yapen Tengah Nature Reserve. Despite the magnificent landscape, Yapen compared to its neighbouring island Biak has remained little explored. Since a short visit by Beccari in 1875 (Solms-Laubach 1883) no further explorations on the pandan flora of the island have been made, thus the pandan flora remains largely unknown.

This paper describes the results of the most recent exploration in Yapen (Keim et al. 2006a). 11 species of Pandanaceae are recorded, of which 3 belong to Freycinetia Gaudich., 2 are new, 7 to Pandanus L.f., and Sararanga sinuosa Hemsl. Except for the latter (Solms-Laubach 1883, Guppy 1887, Hemsley 1894, Stone 1961) the rest of the species are new records.

\section{DESCRIPTION OF SPECIES}

\section{Freycinetia}

\section{Freycinetia allantoidea A.P.Keim, sp. nov. — Fig. 1}

Robustus scandens; infructescentia terminalis vel lateralis, plerumque lateralis, ternatus vel quaternatus; syncarpio allantoido, glaucescenti; stigmata 6 . - Typus: A.P. Keim 808 (BO), Indonesia, New Guinea, Papua, South Yapen District, Yapen Island, Sarawandori, 10 October 2006.

Robust climbing pandan, climbing up to $10 \mathrm{~m}$ high. Stem greyish green, leaf scars obvious, c. $1.2 \mathrm{~cm}$ diam. Leaves spirally arranged in 3 ranks (tristichous); each lanceolate-elongate, c. $43 \mathrm{~cm}$ long, $1.6 \mathrm{~cm}$ wide, acuminate apex, margin with spines only on 1/3 distally and basally; adaxial surface green, glabrous, venation slender; abaxial surface pale green, glaucous white, shiny, venation more obvious, main vein with spines on 1/3 distally; auricle tapered, margin integer. Infructescences terminal

\footnotetext{
${ }^{1}$ Herbarium Bogoriense, Indonesian Institute of Sciences, Jalan Raya, Jakarta, Bogor Km 46 Cibinong, Indonesia.
}

and lateral, mostly lateral (4 individuals observed, only 1 with terminal infructescence), non aromatic, ternate or quaternate, each c. $15 \mathrm{~cm}$ long; peduncle $3-3.5 \mathrm{~cm}$ long, yellowish green, scabrous; bracts 4, bright yellow, unequally, the most inner one being smaller, thick, fleshy, caducous, each $9.5-10 \mathrm{~cm}$ long, c. $5 \mathrm{~cm}$ wide, boat-shaped with acuminate apex. Cephalium sausage-shaped, corky-warted surface, $10-11 \mathrm{~cm}$ long, c. 8.5 $\mathrm{cm}$ circumference $(2.7-3 \mathrm{~cm}$ diam), green, slightly glaucous white, consisting of numerous berries. Stigmas (stigmatic remains) 6 , brown.

Etymology - The epithet name refers to the sausage-shaped appearance of the cephalia.

Distribution - Endemic.

Habitat - Lowland tropical rainforest at about $100 \mathrm{~m}$ altitude.

Vernacular name - Not recorded.

Uses - Not recorded.

Notes - With the robust habit, presence of both terminal and lateral infructescences, and 6 stigmas $F$. allantoidea is a member of the sect. Lateriflorae B.C.Stone (see Stone 1968), which contains other gigantic members, such as F. funicularis (Savigny) Merr., F. lauterbachii Warb., F. papuana Warb., F. pleurantha Merr. \& L.M.Perry, and F. rhodospatha Ridl.

However, the possession of the sausage-shaped corky-warted cephalium of this species is unique. The corky-warted surface of the infructescence refers to the appearance of each berry that is rostrate with a rigid and succulent apex. So far no such structure has been found in any other members of the section.

Furthermore, the obvious bright yellow bracts straightforwardly distinguish $F$. allantoidea from $F$. funicularis and $F$. rhodospatha, which both have conspicuously red to reddish orange bracts (see Rumphius 1743, Ridley 1916).

Freycinetia lauterbachii is known only from male collections (Warburg 1900a, b). Warburg (1900b) mentioned that this species has many bracts, the outer ones green and the innermost ones pink. Stone (1969) regarded it as a synonym of F. funicularis.

Although known only from immature collections $F$. pleurantha shares many morphological characters with F. allantoidea, 

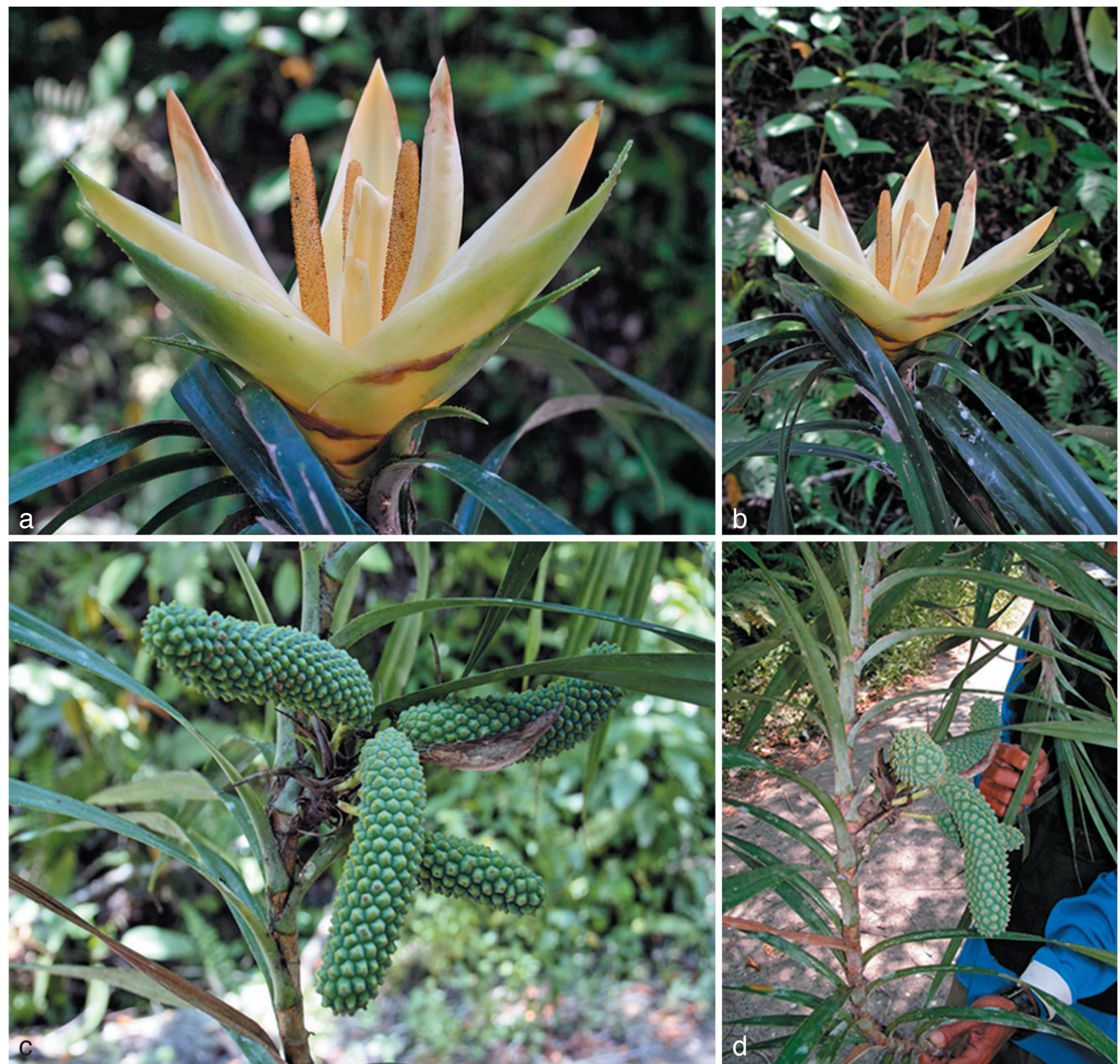

Fig. 1 Freycinetia allantoidea A.P.Keim. a. Male inflorescence showing the obvious yellow bracts; b. terminal male inflorescence; c. sausage-shaped cephalium with a corky-warted surface due to the rostrate rigid-succulent apex berries; d. lateral infructescence. Photos: Y. Purwanto \& A.P. Keim.

such as the obviously glaucous abaxial surface of the leaf, both terminal and lateral (axillary) infructescences, pale glaucous unripe berries, 6-8 stigmas (see Merrill \& Perry 1940). However, there is no information about the colour of the bracts and the structure of the berries, especially the pileus.

With the dimension of the cephalium ( 9 by $3 \mathrm{~cm}$ ), non-succulent ovoid berries, and the 5 or 6 stigmas (Warburg 1900b), $F$. papuana is morphologically most similar to $F$. allantoidea. However, there is no information regarding the leaf or infructescence.

Warburg described the infructescence as "syncarps cylindric 9 $\mathrm{cm}$ long $3 \mathrm{~cm}$ wide, peduncled, peduncle nearly terete, margin little rugulose, $4 \mathrm{~cm}$ long $3 \mathrm{~mm}$ wide, berries not at all connate and not succulent, ovoid, c. $1.5 \mathrm{~cm}$ long, in the middle $1 / 2 \mathrm{~cm}$ wide, apex pyramid-shaped acuminate, below the seeds very much filled".

Martelli (1910) stated that the type of F. papuana (Hollrung 218a) consisted of half a syncarp that without doubt belonged to F. lauterbachii. Stone (1969), however, regarded F. papuana as illegitimate as the type would be a mixed collection, partly belonging to F. funicularis. Up to 1966 the Code ruled that names based on discordant elements (mixed collections) must be rejected, from 1972 on this Article (70) has been deleted, and the combination F. papuana is legitimate. Freycinetia funicularis is now the correct name for F. lauterbachii (fide Stone 1968). The reason for this statement is unclear as Warburg (1900b) did not provide any figures and the type consisting of infructescence and fruits in B were destroyed during WW II. No duplicates are known to exist.

Specimen seen. Only known from the type.

\section{Freycinetia beccarii Solms - Fig. 2}

Freycinetia beccarii Solms (1883) 100. - Type: Beccari s.n. (FI), Indonesia, Papua Barat, Manokwari, Andai, 1872.

Freycinetia globiceps Warb. (1900a) 159; (1900b) 30. - Syntypes: Warburg 20996 (B十), Indonesia, Papua, Sigar; Hollrung 857 (B十), Papua New Guinea, Constantinhafen; Lauterbach 1522 (B十), Finschhafen, 6 January 1890; Lauterbach $2119(\mathrm{~B}+)$, Oertzen-Gebirge, August 1896.

Freycinetia streptopifolia Warb. (1905) 53. - Type: Lauterbach s.n. (B十), Papua New Guinea, Kaiser-Wilhelmsland, April 1902.

Freycinetia ellipsoidalis Merr. \& L.M.Perry (1939) 142. — Type: Brass 7142 (A), Papua New Guinea, Western Province, Palmer River, 2 miles below Black River Junction, June 1936. 

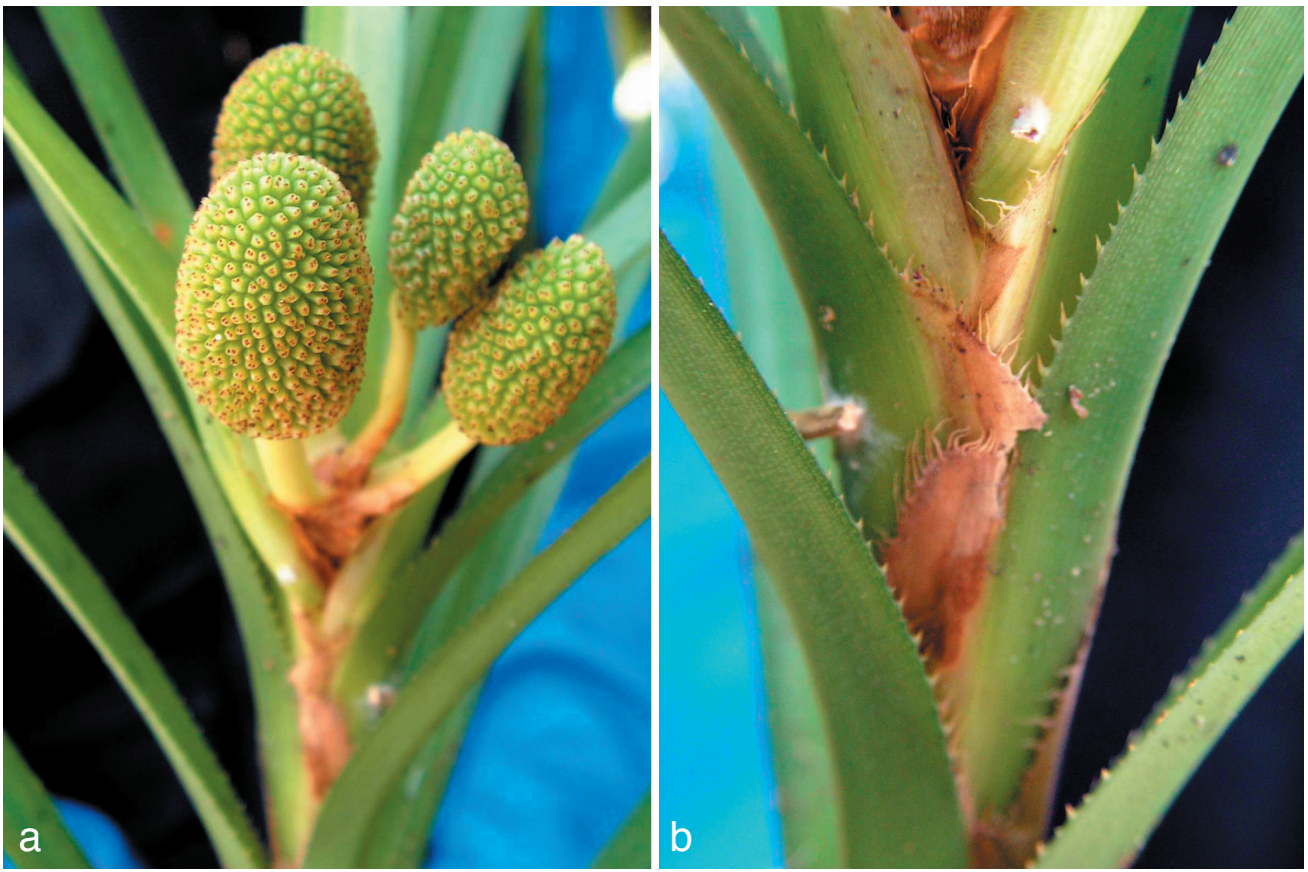

Fig. 2 Freycinetia spinifera A.P.Keim. a. Infructescence with 4 spirally arranged cephalia (quaternate); b. obvious spiny auricles. Photos: Y. Purwanto \& A.P. Keim.

Freycinetia nervosa Merr. \& L.M.Perry (1939) 142. - Type: Brass 6926 (A), Papua New Guinea, Western Province, Palmer River, 2 miles below Black River Junction, June 1936.

Freycinetia elliptica Merr. \& L.M.Perry (1939) 143. - Type: Clemens 3810 (A), Papua New Guinea, Morobe Province, Yunzaing, 4 August 1936.

Slender climbing pandan, climbing up to $10 \mathrm{~m}$ high. Stem greyish green, $0.5-0.7 \mathrm{~cm}$ diam, leaf scars obvious. Leaves arranged in 3 ranks; each leaf elliptical to oblong, $15 \mathrm{~cm}$ long, $4 \mathrm{~cm}$ wide; adaxial surface green, glabrous, venation glabrous, acuminate apex, integer margin except in the most basal part; abaxial surface pale green, venation more obvious, main vein with spines up to $1 / 3$ apically; auricle tapered, apical part with spines. Infructescence terminal, ternate; bracts yellowish green. Cephalium oblong, pale green, c. $2 \mathrm{~cm}$ long, c. $1 \mathrm{~cm}$ diam, consisting of numerous compactly arranged berries; pedicel c. $2 \mathrm{~cm}$ long, glabrous, pale green. Stigmas (stigmatic remains) $2-3$, mostly 2 .

Distribution - Moluccas, northern part of mainland New Guinea, Yapen Island.

Habitat - Lowland tropical rainforest to montane forest at 100-2650 m altitude. In Yapen Island F. beccarii is commonly found at $100 \mathrm{~m}$ altitude.

Vernacular name - Not recorded.

Uses - Not recorded.

Note - This is a new record for Yapen. The result of this study recognises F. ellipsoidalis, F. elliptica, F. globiceps, and $F$. nervosa as synonyms of $F$. beccarii (Table 1 ). The important morphological features used as distinctive characters for the three species are slight and have proven to be continuous (i.e. not discrete). It is also in accordance with Martelli (1910) and Merrill \& Perry (1939) in recognising F. streptopifolia as a synonym of $F$. beccarii.

Specimen seen. INDoneSIA, Papua, Yapen Island, South Yapen District, Sarawandori, 10 Oct. 2006, A.P. Keim 806 (BO!).

\section{Freycinetia spinifera A.P.Keim, sp. nov.}

Gracilis scandens; auricula spinosa; infructescentiae plerumque quaternatae raro ternatae; stigmata plerumque 2, raro 3. - Typus: A.P. Keim 807 (BO!), Indonesia, New Guinea, Papua, Yapen Island, South Yapen District, Sarawandori, 10 October 2006.

Slender climbing pandan, climbing up to $10 \mathrm{~m}$ high. Stem greyish green, $0.5-0.8 \mathrm{~cm}$ diam. Leaves spirally arranged in 3 ranks (tristichous); each lanceolate-elongate, $36-37 \mathrm{~cm}$ long, $1 \mathrm{~cm}$ wide, acuminate apex, integer margin - except in the lower most part (c. 1/3 basally) with minute spines; adaxial surface green, glabrous, venation slender; abaxial surface pale green, glabrous, main nerve obvious, with minute spines on uppermost part; auricle with obvious spines, pectinate, brown; leafsheath pale green. Infructescence terminal, ternate or quaternate, mostly quaternate; peduncle pale yellow, scabrous, $1.7-1.8 \mathrm{~cm}$ long; bracts caducous. Cephalium globose or slightly elongate, c. $2 \mathrm{~cm}$ long, $1 \mathrm{~cm}$ diam, green, consisting of many berries. Stigmas usually 2 , rarely 3 .

Etymology - The epithet means spine-bearing, which refers to the spines on the auricle.

Distribution - Endemic.

Habitat - Lowland tropical rainforest at about $100 \mathrm{~m}$ altitude.

Table 1 Morphological comparisons on leaf dimension, number of stigmas, and the number of cephalia per infructescence in F. beccarii, individuals of F. beccarii found in Yapen Island, F. elliptica, and F. globiceps.

\begin{tabular}{lllc}
\hline Species & Leaf dimension & $\begin{array}{l}\text { Number of } \\
\text { stigmas }\end{array}$ & $\begin{array}{l}\text { Number of cephalia } \\
\text { per infructescence }\end{array}$ \\
\hline Freycinetia beccarii & 8 by $1.8 \mathrm{~cm}$ & 2 & $2-3$ \\
F. beccarii (Yapen individuals) & 15 by $4 \mathrm{~cm}$ & $2-3$, mostly 2 & 3 \\
F. ellipsoidalis & $4.5-5.5$ by $1.5 \mathrm{~cm}$ & $1-2$ & 3 \\
F. elliptica & $8-10$ by $4-4.5 \mathrm{~cm}$ & $1-3$ & 3 \\
F. globiceps & $16-18$ by $2-2.5 \mathrm{~cm}$ & $2-3$, mostly 2 & $2-3$ \\
F. nervosa & $9-11(-14)$ by $3-3.5(-5) \mathrm{cm}$ & $1-3$ & 3
\end{tabular}


Table 2 Morphological comparisons on leaf dimension, cephalium shape, number of cephalia per infructescence and stigma between Freycinetia pectinata, F. rigidifolia, and F. spinifera.

\begin{tabular}{|c|c|c|c|c|}
\hline Species & Leaf dimension & Cephalium shape & $\begin{array}{l}\text { Number of cephalia } \\
\text { per infructescence }\end{array}$ & $\begin{array}{l}\text { Number of } \\
\text { stigmas }\end{array}$ \\
\hline Freycinetia pectinata & $15-20$ by $0.9 \mathrm{~cm}$ & cylindrical & 4 & $4-6(-12)$ \\
\hline F. rigidifolia & 30 by $0.8-1 \mathrm{~cm}$ & oblong-cylindrical & 3 & 2 \\
\hline F. spinifera & $36-37$ by $1 \mathrm{~cm}$ & $\begin{array}{l}\text { slightly elongated globose, } \\
(2 \text { by } 1 \mathrm{~cm})\end{array}$ & $3-4$, mostly 4 & $2-3$, mostly 2 \\
\hline
\end{tabular}

Vernacular name - Not recorded.

Uses - Not recorded.

Notes - In appearance F. spinifera is extremely similar to the West Malesian F. rigidifolia Hemsl., especially regarding the habit, leaf dimension and the cephalium shape. The two species differ only on 2 morphological characters, the numbers of cephalia and stigmas (Table 2).

By the possession of spiny auricles $F$. spinifera seems to be a member of sect. Hemsleyella B.C.Stone, to which F. rigidifolia and F. pectinata Merr. \& L.M.Perry also belong (see Stone 1968).

Until recently the only member of this section known from New Guinea and adjacent areas was F. pectinata of the Solomon Islands. Despite the same slender habit, spiny auricles and quaternate infructescences $F$. spinifera instantly differs from $F$. pectinata in the number of stigmas (Table 2). The number of stigmas in $F$. spinifera varies from $2-3$ (mostly 2 ); while in F. pectinata there are 4-6(-12) (see Merrill \& Perry 1939). A study of the isotype of $F$. pectinata (Brass 3247 , BO) showed that $F$. spinifera is indeed distinct from $F$. pectinata.

Specimen seen. Only known from the type.

\section{Pandanus}

\section{Pandanus conoideus Lam.}

Pandanus conoideus Lam. (1785)372. - Pandanus ceramicus Rumph. (1743) 149, t. 79, nom. inval. - Pandanus ceramicus Kunth (1841) 98, nom. superfl. - Holotype: Rumph., Herb. Amboin. 4: t. 79. 1743.

Bryantia butyrophora Webb ex Gaudich. (1843) t. 20, f. 1-15. — Pandanus butyrophorus (Webb) Kurz (1869) 150. — Lectotype: the plate, designated here.

Pandanus subumbellatus Becc. ex Solms (1883) 96. - Type: Beccari s.n. (FI), Indonesia, Moluccas, Aru Archipelago, Wokam Island, Giabu-Lenga (Jabulenga).

Pandanus macgregorii F.Muell. ex Solms (1889) 511. - Type: Mac Gregor s.n. (B十), nom. prov., inval. ("beschreibe ich vorläufig"), Papua New Guinea, D’Entrecasteaux Islands, Fergusson Island.

Pandanus cominsii Hemsl. in Hook. (1900) t. 2654. - Type: Rev. Comins 363 (K), Papua New Guinea, Solomon Islands, Florida Group, Siota Island.

Pandanus hollrungii Warb. (1900a) 161, nom. nud.; (1900b) 71. - Type: Hollrung s.n. (B十), Papua New Guinea, presumably from mainland Papua New Guinea (then Kaiser-Wilhelmsland).

Pandanus hollrungii Warb. forma caroliniana Martelli (1912) 66. - Type: Kraemer s.n. (B十), Micronesia Federation, Caroline Islands, Truck Island, Tol Uman.

Pandanus englerianus Martelli (1912) 65. - Syntypes: Penloup 5 (FI), Peekel 91 (B十), Naumann s.n. (B十), Papua New Guinea, Neu Mecklenburg (= New Ireland), 1908.

Pandanus magnificus Martelli (1912) 65. - Type: Kraemer s.n. (B†), Papua New Guinea, Admiralty Islands, Manus Island.

Pandanus ruber H.St.John (1961) 579. - Type: Brass 5463 (BRI; iso NY), Papua New Guinea, Central, Bella Vista.

Pandanus cominsii Hemsl. var. micronesicus B.C.Stone (1965) 5. - Type: B.C. Stone $5340(\mathrm{PH})$, Micronesia, Caroline Islands, Truk Islands, Tol, $7^{\circ} 25^{\prime} \mathrm{N}, 151^{\circ} 47^{\prime} \mathrm{E}$, cultivation, 30 January 1965.

Pandanus latericius B.C.Stone (1965) 2. - Type: B.C. Stone 2637 (BISH), Papua New Guinea, New Ireland Island, Kavieng.

Pandanus minusculus B.C.Stone (1965) 3. - Type: B.C. Stone 2627 (BISH), Papua New Guinea, New Ireland Island, Kavieng.

Pandanus erythros H.St.John (1968) 515. - Type: Carr 15922 (BM, L), Papua New Guinea, Central, Central, Isuarava.
Pandanus plicatus H.St.John (1968) 517. - Type: Carr 12590 (BM), Papua New Guinea, Central, Koitaki.

Pandanus rubrispicatus H.St.John (1968) 519. - Type: Not designated, nom. nud, anglice, 'Northeast New Guinea'.

Pandanus cominsii Hemsl. var. augustus B.C.Stone (1972b) 109. - Type: B.C. Stone 2570 (fem.) (BISH), Solomon Isl., Santa Isabel Isl., VulavuThathaje trail, along south-west coast, 17 October 1957.

Solitary tree pandan, 3-10 m high. Prop roots present, obvious. Stem branched. Leaves in a rosette, spirally arranged in 3 ranks (tristichous); each lanceolate-elongate, c. $180 \mathrm{~cm}$ long, 3-5 cm wide, margin with spines; adaxial surface dark green, glabrous, adaxial ventral pleats present; abaxial surface pale green, main vein apparent, with minute spines, recurved spines obvious. Infructescence terminal, solitary; peduncle $38-44 \mathrm{~cm}$ long, c. $5.4 \mathrm{~cm}$ diam (c. $17 \mathrm{~cm}$ circumference). Cephalium cylindrical (elongated ellipsoidal) trigonal, bright yellow to red and crimson, 42-70(100-110) cm long, 9.6-11 cm diam (30-34.5 cm circumference), slightly covered with persistent bracts; pedicel white; composed of numerous drupes. Drupe obviously trigonal (triangular), pericarp fatty, yellow or red.

Distribution - Moluccas, New Guinea and adjacent islands, Bismarck Archipelago, Solomon Islands and the islands of Micronesia (i.e. Caroline Islands).

Habitat - Cultivated from sea level up to 2000 m altitude. Never found in the wild. In Yapen Island, the red and yellow varieties are cultivated almost in every part of the South and East districts except in the Menawi area, where only the red variety is planted.

Vernacular names - Pandan Buah Merah (Indonesia), Pandan Séran (Malay-Moluccan dialect), Saun (Moluccas-Seran), Kleba (Moluccas-Buru), Siho (Moluccas, North HalmaheraGalela), Goroko ina Ngauku (Moluccas, North HalmaheraTobias), Kobokana (Yapen-Kerenui), Awone Mangkaki (YapenMenawi, for individuals with yellow cephalia), Awom Mangkaki (Yapen-Mantembu, for individuals with yellow cephalia), Awone Waransir (Yapen-Mantembu, for individuals with red cephalia), Abo (Yapen-Menawi, for individuals with red cephalia), Saj (PapuaWamena), Marita (Pidgin of Papua New Guinea), Bunam (New Ireland-Pala), Bunumia (New Ireland-Kuanua), Vurume (New Ireland-Lamekot), Deg (New Ireland-Pala), Si-tararak (New Ireland-Lamekot), Besbes (New Ireland-Ugana).

Uses - Leaves are used for mats. Vegetable fat extracted from the pericarp is used as sauce, medicine, and tonic. The cephalia are economically important and sold in the local market. Peekel (1984) and French (1986) under P. englerianus described a usage and method of preparation of the pulp extracted from the pericarp that is similar to the way $P$. conoideus is treated.

Notes - The presence of $P$. conoideus in Yapen Island is a new record. It is a good example of a species with a widespread distribution and an outstanding spectrum of morphological variation. The differences between $P$. conoideus and the numerous species listed above are slight and are merely in the dimensions of the leaves and drupes (Table 3 ) underrating the obvious similarities in the shape of the cephalia and stigmas. Despite the differences in the size all taxa listed above each have an obvious long cylindrical trigonally (triangular)-shaped yellow to 
Table 3 Morphological comparisons on the sizes of leaf, cephalium, drupe and shape of cephalium between Pandanus conoideus and some species listed above as synonyms.

\begin{tabular}{|c|c|c|c|c|}
\hline Species & Size of leaf $(\mathrm{cm})$ & Size of cephalium (cm) & Size of drupe (mm) & Shape of cephalium \\
\hline Pandanus cominsii & $60-120$ by $5-6$ & 30 by $5-6$ & $12-16$ by 3 & cylindrical-trigonal \\
\hline P. conoideus & $180-200$ by $3-12$ & $42-110$ by $9.6-11$ & 25 by 3 & cylindrical-trigonal \\
\hline P. englerianus & 250 by 10 & 60 by 12 & 18 by $5-6$ & slightly trigonal \\
\hline P. hollrungii & no data (leaf not collected) & 35 by $4-7$ & $11-13$ by $2.5-3$ & cylindrical-subtrigonal \\
\hline P. hollrungii forma caroliniana & no data (leaf not collected) & 35 by $4-7$ & $15-18$ by $2.5-3$ & cylindrical-subtrigonal \\
\hline P. latericus & 205 by 4 & 35 by 9 & 12 by 3 & cylindrical-trigonal \\
\hline P. macgregori & 136 by 4.5 & $23-25$ by 5 & 15 by 6 & cylindrical-subtrigonal \\
\hline P. magnificus & no data (leaf not collected) & 65 by 11 & $15-16$ by $3-5$ & cylindrical-trigonal \\
\hline P. minusculus & $150-265$ by 5 & 23 by 5 & 12 by 4 & cylindrical-trigonal \\
\hline P. plicatus & $100-200$ by $4-5$ & 20 by 6.3 & 22 by 4 & cylindrical-trigonal \\
\hline P. ruber & 172 by 10.2 & 42 by 10.5 & $13-15$ by $3-4.5$ & cylindrical-trigonal \\
\hline P. subumbellatus & $200-300$ by 6 & 20 by $8-10$ & $12-15$ by 3 & cylindrical-subtrigonal \\
\hline
\end{tabular}

red cephalium, a characteristic of $P$. conoideus, which has been recorded as early as Rumphius (1743). Keim et al. (2006a) have suggested that the size of the cephalia from individuals found in the island tends to be smaller than those, which are found in the mainland. The length of cephalium collected from individuals in Yapen rarely exceeds $50 \mathrm{~cm}$, while those found in the Wamena highlands of Indonesian New Guinea can reach $100-110 \mathrm{~cm}$ (Keim et al. 2006b). This current study is also in accordance with Stone (1982) and Jebb (1992) in placing $P$. erythros and $P$. plicatus as synonyms of $P$. conoideus and recognising $P$. rubrispicatus as a nomen nudum. Nevertheless these species share three important morphological characters with $P$. conoideus, the long cylindrical-trigonal and red cephalium with small vertical flat stigmas (St John 1968). The placement of species listed above as synonyms has the consequence that $P$. conoideus is now also known to occur in the Caroline Islands (Micronesia), and so is a new record for $P$. conoideus. As $P$. conoideus has never been found in the wild, the widespread distribution of $P$. conoideus is undoubtedly due to human activities rather than to natural causes (Stone 1982, Hyndman 1984, Walter \& Sam 2002).

Specimens seen. IndonesIA, Papua, Yapen Island, East Yapen District, Kerenui, 19 Sept. 2006, A.P. Keim 781 (BO!); South Yapen District, Mantembu, 23 Sept. 2006, A.P. Keim 782 (BO!); Menawi, 25 Sept. 2006, A.P. Keim 783 (BO!), A.P. Keim 784 (BO!); Mantembu, 26 Sept. 2006, A.P. Keim 786 (BO!).

\section{Pandanus dubius Spreng.}

Pandanus dubius Spreng. (1826) 897. - Folium baggea maritimum Rumph. (1743) 151, t. 80, nom. inval. - Pandanus bagea Miq. (1855) 159, nom. superfl. - Type: Rumph., Herb. Amboin. 4: t. 80. 1743. — Epitype: Robinson Pl. Rumph. Amboin. 55 (US; iso A, BM, BO, F, K, L (Carpol. 10415), $\mathrm{MO}, \mathrm{NSW}, \mathrm{NY}$ ), designated here, Indonesia, Moluccas, Amboina, Latuhalat, along the seashore, 22 September 1913.

Folium baggea verum sive Pandanus magnus Rumph. (1743) 150, nom. inval. - Included here by Warburg (1900b), but Merrill (1917: 82) thought that this possibly is $P$. tectorius Parkinson ex J.P. du Roi.

Pandanus latissimus Blume (1835) 175, 202, t. 53, nom. nud.; ex Miq. (1851) 29. - Type: Indonesia, Moluccas, Banda. Not found in L.

Barrotia tetrodon Gaudich. (1843) t. 13, f. 1-8. - Pandanus tetrodon (Gaudich.) Balf.f. (1878) 63. - Type: Gaudichaud s.n. (P), Mariana Islands

Hombronia edulis Gaudich. (1843) t. 22, f. 17. - Pandanus edulis (Gaudich.) de Vriese in Hook. (1854) 264, non Thouars, 1808. - Type: Gaudichaud s.n. (P), Mariana Islands.

Pandanus bidoer Jungh. (1853) 268. - Type: Junghuhn s.n. (L. sh. 903.257697), Indonesia, Java, Bantam, Ujong Kulon, G. Payong, 14 May 1846.

Pandanus macrocarpus Vieill. (1861) 51. - Barrotia macrocarpa (Vieill.) Brongn. (1875) 279, t. 14, f. 1. - Type: Pancher 761 (P), New Caledonia, in the mountains near Diaoé. See note.

Pandanus leram auct. non Jones ex Voigt: Kurz (1867) 105. — Pandanus andamanensium Kurz (1869) 148. — Pandanus leram Jones ex Voigt var. andamanensium (Kurz) B.C.Stone (1975a) 118. - Type: Kurz s.n. (CAL) India, Andaman Islands.
Pandanus compressus Martelli (1905) 363. - Pandanus dubius Spreng. var. compressus (Martelli) B.C.Stone (1975b) 50. - Type: Guppy s.n. (K), Solomon Islands.

Pandanus yamagutii Kaneh. (1936) 544. - Type: R. Kanehira 3721 (FU), Micronesia, Truk Island, Truk District Office, September 1935.

Robust solitary tree pandan, 10-15 m high. Prop roots obvious, more than $1 \mathrm{~m}$ high, spiny; outer bark greyish brown; inner bark whitish crème. Leaves in a rosette, spirally arranged in 3 ranks (tristichous); lanceolate-elongate, c. $93 \mathrm{~cm}$ long, c. $11 \mathrm{~cm}$ wide, slightly rotundate margin with minute spines; adaxial surface green, glabrous, adaxial ventral pleats absent, venation slender green; abaxial surface pale green, venation more obvious, green, recurved spines absent. Infructescence solitary, terminal, $62-65 \mathrm{~cm}$ long; peduncle $28-30 \mathrm{~cm}$ long, glabrous. Cephalium globose, 34-35 cm long, c. $20.7 \mathrm{~cm}$ diam (circumference c. 65 $\mathrm{cm}$ ), green, glaucous white, composed of phalanges. Phalange ellipsoidal ovate, hard, pale green, glaucous white, $5-6 \mathrm{~cm}$ long, c. $4 \mathrm{~cm}$ wide; stigmas 2-7 arranged in 1 linear row.

Distribution - Andaman Islands, Malesia, Bismarck Archipelago, Solomon Islands, Caroline Islands (i.e. islands of Micronesia), Palau Island, Mariana Islands, Fiji, Tonga, Vanuatu (New Hebrides), Niue Island.

Habitat - Coral and rocky shores, never found far inland.

Vernacular names - Bidur (Java, Sunda), Pandan wong (Sunda), Pandan pantai buah durian (Malay-Yapen), Haun lainulun (Moluccas-Ambon), Haun pantai (Moluccas-Ambon), Pung (Moluccas, South Halmahera-Weda, North HalmaheraTobias), Boku (Moluccas, North Halmahera-Galela, MoluccasTernate), Bou (Moluccas-Tidore), Vaum (New Ireland-Kuanua), Lau (New Ireland-Pala), Fom, Faum (New Ireland-Lamekot), Na Vaku (Vanuatu-Nguna), Navaka (Vanuatu-Tongariki), Pohk (Caroline Islands-Truk), Poko (Palau), Meu-yok (Caroline Islands-Kusai), Pafung (Marianas Islands-Saipan).

Uses - Leaves are used for mats and roofing. In Yapen the leaves are used as wrappers for steaming fish. This usage has never been reported before. In the Moluccas the leaves are used in preparing (i.e. cooking) the Sago (Heyne 1927), in which the starch is enwrapped with the leaves and then baked, a practise which is not found in Yapen. The cephalium is not eaten in Yapen, but it is in the New Hebrides (Stone 1967) and elsewhere in the Pacific region (Walter \& Sam 2002). The flavour is much like that of coconut meat.

Notes - Martelli $(1904,1913)$ suggests that $P$. macrocarpus Vieill. is a mixed collection which he split up in $P$. macrocarpus s.s. and $P$. veillardii Martelli. Brongniart (1875) did not comment on this, but noted that the description of the fruits did not agree with what he had seen, while in CAEN there was a fruit of $P$. odoratissimus under this name. He attributed this to a mixup of labels.

The presence of $P$. dubius in the Andaman Islands and Yapen are new records. In Java in some phalanges in the apical part 
Table 4 Morphological comparisons on the sizes of the phalanges, number of stigmas and their arrangement between Pandanus andamanensium, $P$. bidoer, P. compressus, P. dubius, P. leram, and P. yamagutii.

\begin{tabular}{|c|c|c|c|}
\hline Species & Size of phalange $(\mathrm{cm})$ & Number of stigma per phalange & Arrangement of stigmas in a phalange \\
\hline Pandanus andamanensium & $5-7$ by 4 & $\begin{array}{l}\text { 1-2 ( } 3-5 \text { according to Hooker } 1894 ; 2-3 \text { according } \\
\text { to Backer \& Bakhuizen van den Brink Jr. 1968) }\end{array}$ & 1 linear row \\
\hline P. bidoer & $8-14$ by $4-8$ & $2-5$ & 1 linear row \\
\hline P. compressus & $7-15$ by 4 & $3-4$ or up to $5-7$, rarely only 1 & 1 linear row \\
\hline P. dubius & $\begin{array}{l}5-6 \text { by } 4 \text { ( } 10-14 \text { by } 5-7 \text { in individual } \\
\text { found in Java according to } \\
\text { Keim et al. } 2006 \mathrm{c})\end{array}$ & $\begin{array}{l}2-3 \text {, but phalanges in the distal (apical) part can } \\
\text { be seen with only } 1 \text { stigma }\end{array}$ & 1 linear row \\
\hline P. leram & $12-14$ by $10-12$ & $6-12$ & 1 linear row \\
\hline P. yamagutii & 3 by $1.5-1.7$ & $2-3$ & 1 linear row \\
\hline
\end{tabular}

of the cephalium there may be only a single stigma (Keim et al. 2006c). Thus the difference is insufficient to keep the two species apart and $P$. andamanensium is submerged. Despite the difference in the number of stigmas in a phalange, the stigmas in these two species are arranged in a single row (Table 4).

Actually, Kurz (1869) himself already noted that $P$. andamanensium is very similar to $P$. dubius and would differ only by the number of stigmas per phalange, 1-2, while $P$. dubius would have $2-3$. Although when comparing these two species Kurz cited the protologue of $P$. dubius, the possession of 2 stigmas in a linear row in $P$. dubius was not discussed. Warburg (1900b) mentioned that $P$. andamanensium is very much the same as $P$. dubius and differs only in the size of the phalange and numbers of stigmas but still kept them as two distinct species. Backer \& Bakhuizen van den Brink Jr. (1968) reported that phalanges from individuals found in Java regarded to belong to $P$. andamanensium were observed with $2-3$ stigmas in a row; thus fitting $P$. dubius.

The same argument is also applied when placing $P$. compressus in the synonymy of $P$. dubius. The arrangement of 3-4 stigmas in a linear row per phalange here (Martelli 1905) is slightly different from $P$. dubius. Stone (1967) noted that $P$. compressus is very similar to $P$. dubius and differs particularly in the number of stigmas (Table 3 ), and seeds (usually $2-3$, while usually solitary in P. dubius), and the position of the seed (basal, while central in $P$. dubius). In the present study these characters only vaguely distinguish $P$. compressus from $P$. dubius. Although it rarely happens $P$. compressus can also possess a phalange with 1 stigma (Stone 1968), so its range overlaps that of $P$. dubius. On the other hand, although the phalanges of $P$. dubius are usually found with a single seed, sometimes they may have more, thus agreeing with $P$. compressus.

The result of my study indicates that $P$. bidoer is also a synonym of $P$. dubius, which is in accordance with the opinions of Warburg (1900b), Koorders (1911, 1913, see also KoordersSchumacher 1913) and Stone (1972a) but not with Backer \& Bakhuizen van den Brink Jr. (1968) who treated P. bidoer as a distinct species.

The main differences between $P$. bidoer and $P$. dubius would be in the dimensions of the leaf (200 by $40 \mathrm{~cm}$ against $93-500$ by $11-14 \mathrm{~cm}$ in P. dubius) and phalanges (Table 4), which are regarded here as insufficient. The length (and corresponding width) of the leaves in a single individual of $P$. dubius may vary from less than 100 up to $500 \mathrm{~cm}$. The size of phalanges from an individual of $P$. dubius (identified by $2-3$ stigmas in 1 linear row) found in Java can reach $10-14$ by $5-7 \mathrm{~cm}$ (Keim et al. 2006c). Thus $P$. bidoer cannot be distinguished.

Pandanus yamagutii is also treated here as a synonym of $P$. dubius. The straightforward similarity with $P$. dubius is in the number of stigma per phalange (Table 4 ). The smaller size of the phalange described for $P$. yamagutii is due to the immature nature of the cephalium (Kanehira 1936). The rest of the characters match $P$. dubius and even Kanehira mentioned that the species was a member of a section that is recorded chiefly from the Asiatic continent and the Philippines (see Kanehira 1936).

Stone (1975a) regarded $P$. andamanensium as a variety of $P$. leram, $P$. leram var. andamanensium. He believed that it represents the wild form of the cultivated $P$. leram. I am not in accordance with this. Pandanus leram has several straightforwardly distinctive morphological characters, especially the number of stigmas in a row (Table 4). Furthermore, it is a native of the Nicobar Islands. It is only in Ceylon that this species has never been found in the wild. Until data from molecular study become available, the 'polyploidy' theory involving the 'wild' $P$. andamanensium and the 'cultivated with doubled number of stigmas' P. leram as was suggested by Stone (1975a) is regarded here as tentative, thus best avoided. Based on the morphological data available at present $P$. andamanensium is undoubtedly the same as $P$. dubius.

Specimen seen. IndonesiA, Papua, Yapen Island, South Yapen District, Menawi, beach, 30 Sept. 2006, A.P. Keim 788 (BO!).

\section{Pandanus kaernbachii Warb.}

Pandanus kaernbachii Warb. (1900a) 159, nom. nud.; (1900b) 49. - Syntypes: Kaernbach s.n. (B十), Hollrung s.n. (B†), German New Guinea, KaiserWilhelmsland.

Pandanus scabribracteatus Martelli (1929) 139. - Holotype: Brass 987 (A), Papua New Guinea, Central, Vailala River.

Large solitary tree pandan, c. $10 \mathrm{~m}$ high. Prop roots present, obvious, 2-5 m high, spiny. Stem branched, spiny, pale greenish cream to yellowish cream. Leaves in a rosette, spirally arranged in 3 ranks (tristichous); each lanceolate-elongate, 240-250 $\mathrm{cm}$ long, 9-11 cm wide, margin with spines; adaxial surface green, glabrous, main vein pale green, adaxial ventral pleats obvious; abaxial surface pale green, glaucous white, venation more obvious, recurved spines absent, basal part pale yellow to white; leafsheath pale yellow to white. Infructescence terminal, spike of 2 cephalia. Cephalium globose, 21-22 cm long, c. 16 $\mathrm{cm}$ diam (c. $50 \mathrm{~cm}$ circumference), composed of phalanges; phalanges compactly and densely arranged; each phalange composed of 8-10 drupes. Drupe green on distal part, yellow on basal part, hard; stigmatic remains hard, brown.

Distribution - Eastern and southern parts of mainland Papua New Guinea, Bismarck Archipelago, and Yapen Island.

Habitat - Coastal and freshwater swamp.

Vernacular name - Pandan pantai buah banyak (Malay).

Uses — Leaves are used for making mats. The cephalium is not eaten.

Note - The presence of $P$. kaernbachii in Yapen Island is a new record.

Specimen seen. INDONESIA, Papua, Yapen Island, South Yapen District, Sarawandori, about 1 hour drive West of Serui, western side of the island, 10 Oct. 2006, A.P. Keim 801 (BO!). 


\section{Pandanus krauelianus K.Schum.}

Pandanus krauelianus K.Schum. (in K.Schum. \& Hollrung 1889) 17. - Holotype: Hollrung $164(\mathrm{~B} \dagger)$, German New Guinea, Kaiser-Wilhelmsland, Kollua near Finschhafen.

Pandanus silvestris Rumph. (1743) 145, t. 77 ('Keker wassi'), nom. inval. - Pandanus rumphii Warb. (1900b) 84, non Gaudich. 1846. — Pandanus ceramicus Kunth (var.) sylvestris Kunth (1841) 98. - Type: Rumph., Herb. Amboin. 4: t. 77. 1743. Warburg (1900b) erroneously used 'montanus' as the name for this plate. Rumphius had two 'species', 'silvestris' and 'montanus'. The plate is of 'silvestris', Rumphius wrote. - Epitype: Robinson Pl. Rumph. Amboin. 31 (US; iso A, BM, BO!, F, K, L!, MO, NSW, NY), designated here, Indonesia, Moluccas, Amboina, Lateri, 9 September 1913.

Pandanus montanus Rumph. (1743) 145 ('Keker ewan'), nom. inval. - Pandanus montanus Miq. (1855) 161, non Bory 1804. - Pandanus terrestris Warb. (1900b) 84. - Type: Not indicated. — Merrill (1917) erroneously identified the Rumphian plate with this.

Pandanus amboinensis Warb. (1900b) 83. - Type: De Vriese s.n. (L sh. 898.273-5 \& 6), Indonesia, Moluccas, Amboina, Ambon.

Pandanus flabellistigma Martelli (1905) 366. - Type: Kurz s.n. (CAL), Cult. in Hort. Bot. Buitenzorg.

Pandanus tabbersianus Rendle ex Gibbs (1917) 198. - Type: Gibbs 6213 (BM), Indonesia, Papua, Manokwari track to Ambani (Amban), January 1914.

Pandanus kivi Martelli (1929) 140. - Type: Brass 1557 (A), Territory of Papua, Eastern Div., Lower Mori River, 28 May 1926.

Pandanus microdontus Merr. \& L.M.Perry (1939) 177, t. 1, f. 18. - Type: Brass 7695 (A; iso L), Papua New Guinea, Lake Daviumbu, Middle Fly River, September 1936.

Pandanus xanthocarpus Merr. \& L.M.Perry (1939) 179, t. 1, f. 17. - Type: Brass 8487 (A; iso L), Papua New Guinea, Western Province, Wassi Kussa River, Tumbuke, December 1936.

Pandanus cernuifolius Merr. \& L.M.Perry (1939) 180, t. 1, f. 20. - Type: Brass 3916 (A; iso BRI, NY), Papua New Guinea, Central Province, Ononge Road, Dieni, 1 May 1953.

Pandanus zea H.St.John (1960) 239, t. 8. - Type: Brass 19293 (BRI; iso L), Australia, Queensland, Cape York Pen., Iron Range, 22 June 1948.

Pandanus flavicarpus B.C.Stone (1965) 2. - Type: B.C. Stone 2478 (LAE), Papua New Guinea, Solomon Islands, Santa Ysabel.

Pandanus nakanaiensis B.C.Stone (1965) 2. - Type: NGF 6440 (Floyd) (LAE), Papua New Guinea, New Britain.

Pandanus roseus B.C.Stone (1965) 2. - Type: B.C. Stone 2559 (LAE), Papua New Guinea, Solomon Islands, Rendova Island.

Pandanus rubellus B.C. Stone (1965) 2. - Type: B. C. Stone 2565 (LAE), Papua New Guinea, Bougainville Island.

Pandanus spodiophyllus B.C.Stone (1965) 2. - Type: B.C. Stone 2617 (LAE), Papua New Guinea, New Britain.

Pandanus biciliatus H.St.John (1973) 64, t. 311. - Type: Brass 28746 (K; iso L, US), Papua New Guinea, Woodlark Island, Kulumadau rainforest, 14 November 1956.

Pandanus biformatus H.St.John (1973) 67, t. 312. - Type: Brass 23765 (K; iso A, L, LAE), Papua New Guinea, Milne Bay Prov., Gwariu River, Biniguni Camp, 2 August 1953.

Pandanus luteus H.St.John (1973) 77, t. 318, 319. - Type: Brass 24732 (K; iso LAE), Papua New Guinea, Goodenough Island, eastern slope, mossy oak forest, 8-15 October 1953.

Pandanus croceus B.C.Stone (1974) 23, t. 9-11. - Type: B.C. Stone 10290 $=\mathrm{LAE} 53590$ (Stone \& Streimann) (LAE; iso A, BISH, BRI, CANB, K, L, US), Papua New Guinea, Admiralty Islands, Manus Island, hills above Lorengau, 18 June 1971.

Pandanus auritus H.St.John ex Huynh (1976) 93, gallice, nom. nud. — Voucher: Brass 27272 (L, incl. Carpol. 13298), Papua New Guinea, Fergusson Isl., Agamoia, 22 June 1956.

Pandanus bidrupaceus H.St.John ex Huynh (1976) 93, gallice, nom. nud. - Voucher: Brass 28120 (L), Papua New Guinea, Sudest Isl., Rambuto, 16 September 1956.

Pandanus cernuus H.St.John ex Huynh (1976) 92, gallice, nom. nud. - Voucher: BW 6582 (Koster) (L), Indonesia, Papua, Kebar, Sanopi, 17 February 1958.

Pandanus flexibilis H.St.John ex Huynh (1976) 93, gallice, nom. nud. - Voucher: Brass 32315 (LAE), Papua New Guinea, Morobe Prov.

Pandanus imbrialis H.St.John ex Huynh (1976) 93, gallice, nom. nud. — Voucher: Brass 5655 (FI), Papua New Guinea.

Pandanus maneauensis H.St.John ex Huynh (1976) 93, gallice, nom. nud. — Voucher: Brass 23461 (LAE), Papua New Guinea, Milne Bay Prov.

Pandanus reconditus H.St.John ex Huynh (1976) 93, gallice, nom. nud. — Voucher: Brass 29252 (LAE), Papua New Guinea, Morobe Prov.
Pandanus wauensis H.St.John ex Huynh (1976) 93, gallice, nom. nud. - Voucher: NGF 24963 (Womersley) (L), Papua New Guinea, Morobe Prov.

Pandanus kosteri B.C.Stone (1987) 435, t. 5. - Type: BW 6852 (Koster) (L), Indonesia, West Irian, Kebar, Sanopi, 17 February 1958.

Pandanus beccarii auct. non Solms: K.Schum. (1887) 192.

Usually solitary, sometimes clustered tree pandan, 2-3 m high. Prop roots present, not obvious, less than $1 \mathrm{~m}$ high (c. $50 \mathrm{~cm}$ high). Stem slender, branched, greyish green to whitish cream, spiny. Leaves in a rosette, spirally arranged in 3 ranks (tristichous); lanceolate-elongate, $150-250 \mathrm{~cm}$ long, $7-9 \mathrm{~cm}$ wide, acuminate apex, margin with spines throughout the length; adaxial surface green to yellowish green, glabrous, venation slender, adaxial ventral pleats present; abaxial surface pale green, glaucous white, venation more obvious, main vein with spines, recurved spines obvious, basal part yellowish green to whitish green; leafsheath yellowish green to whitish green. Male inflorescence solitary, terminal, fragrant, c. $100 \mathrm{~cm}$ long, consisting of 10 inflorescence branches, each sausage-shaped, covered with white bracts, bracts c. $33 \mathrm{~cm}$ long, c. $12 \mathrm{~cm}$ wide, stamens numerous. Infructescence solitary, terminal, hanging, $43-57 \mathrm{~cm}$ long; peduncle glabrous, pale green, $20-40 \mathrm{~cm}$ long. Cephalium covered with layers of persistent green turns to yellowish green and finally cream orange bracts, only terminal part seen, in appearance resembling corn (Zea mays), oblong to elongated ellipsoidal, slightly triangular to subtruncate, pinkish orange (salmon pink) to orange, $17-23 \mathrm{~cm}$ long, $8-11 \mathrm{~cm}$ diam (25-34 cm circumference) consisting of numerous compactly arranged drupes. Drupe 20-21 mm long, 4-5 mm wide; stigma sunken, hard, brown, not sharp, ascending.

Distribution - Moluccas, mainland New Guinea, Yapen Island, Bismarck Archipelago, D'Entrecasteaux Islands, Solomon Islands and northern part of Australia (Queensland).

Habitat - Mangrove, lowland swampy up to submontane forests from 0 up to around $1600 \mathrm{~m}$ altitude. In Yapen abundantly found at around $100 \mathrm{~m}$ altitude.

Vernacular names - Raintui (Yapen-Menawi), Rei (Manus), I (New Ireland-Kuanua), Isis (New Ireland-Pala), Siliut (New Ireland-Lamekot).

Uses - In Yapen the cephalium is eaten. The usage and method of preparing the fatty substrate extracted from the pericarp is similar to that of $P$. conoideus Lam. Indeed, in the other areas in New Guinea, P. krauelianus is used as a substitute to $P$. conoideus (Stone 1992). The leaves are used for mats.

Notes - Prior to the present study $P$. krauelianus was only known from the eastern part of mainland Papua New Guinea and the Bismarck Archipelago (Stone 1992). As it has now also been found in Yapen this is a new record. Several names have turned out to be synonyms. Except for relatively slight differences in the sizes of leaf, cephalium, drupe and its colour, there appear to be no significant morphological differences with $P$. krauelianus (Table 5). Stone (1992) mentioned the semidwarf habit of $P$. kosteri (1.7-2 $\mathrm{m}$ high), the red colours of bracts and cephalium as diagnostic characters for the species. Indeed, compared to the other members of sect. Maysops H.St.John $P$. kosteri is the smallest one. However, the discovery of 2-3 $\mathrm{m}$ high individuals straightforwardly belonging to $P$. krauelianus as is indicated by the salmon pink to orange cephalia covered with layers of green, bright yellowish green to cream orange bracts in Yapen undermined the recognition of $P$. kosteri as a distinct species and it is therefore reduced here. This has a further consequence that $P$. krauelianus is now to be recognised as a widespread species occurring from the Moluccas through the mainland of New Guinea and its adjacent islands to the Solomon Islands and the northern part of Australia with a wide spectrum of morphological variation. Species with such a great variability are not uncommon in Pandanus as can be seen in $P$. conoideus, $P$. odoratissimus L.f., and $P$. polycephalus Lam. 
Table 5 Morphological comparisons on the sizes of leaf, cephalium, drupe and colour of drupe between Pandanus krauelianus and several species placed in this paper as synonyms.

\begin{tabular}{|c|c|c|c|c|}
\hline Species & Size of a leaf $(\mathrm{cm})$ & Size of a cephalium (mm) & Size of a drupe (mm) & Colour of a drupe \\
\hline Pandanus amboinensis & 180 by $5.5-7.4$ & $170-420$ by $35-105$ & $15-19$ by $4-6$ & greyish yellow \\
\hline P. cernuifolius & $125-215$ by $4.4-5.3$ & 80 by 40 (immature) & 16 by 1 & orange \\
\hline P. croceus & $200-400$ by $7-12$ & $280-410$ by $85-130$ & 13 by $4-5$ & yellow to pale yellowish orange \\
\hline P. flavicarpus & 300 by 13 & 500 by 150 & 23 by 5 & orange \\
\hline P. kosteri & $68-100$ by $2.5-3.7$ & 65 by 35 & 15 by $4-5$ & red \\
\hline P. krauelianus & $150-250$ by $7-9$ & $170-230$ by $80-110$ & $20-21$ by $4-5$ & pinkish orange (salmon pink) to orange \\
\hline P. microdontus & $275-300$ by $6.8-8.5$ & 250 by 80 & 20 by 4 & pink \\
\hline P. rubellus & 230 by 6.5 & 300 by 120 & 25 by 6 & reddish orange \\
\hline P. spodiophyllus & 210 by 6 & 280 by 110 & 30 by $8-12$ & orange \\
\hline P. tabbersianus & $140-300$ by $4.2-6.4$ & $400-410$ by $90-95$ & $18-21$ by $4-5$ & orange \\
\hline P. xanthocarpus & $150-170$ by $7.5-8$ & 220 by 110 (immature) & $30-32$ by $3-4$ & pale yellow \\
\hline P. zea & $150-172$ by $4.1-4.2$ & $200-220$ by $70-75$ & $14-17$ by $5.5-9$ & ellow \\
\hline
\end{tabular}

The presence of $P$. krauelianus in the Moluccas, the western side of mainland New Guinea, Solomon Islands, and northern part of Australia are new records.

Specimens seen. IndonesIA, Papua, Yapen Island, South Yapen District, Randu Ayaipé, hill close to the road to Pasir Putih, 5 Oct. 2006, A.P. Keim 789 (BO!); on the way from Serui to Menawi, close to Kelapa 2 area, 7 Oct. 2006, A.P. Keim 798, male individual (BO!); Sarawandori, about 1 hour drive West of Serui, western side of the island, 10 Oct. 2006, A.P. Keim 802 (BO!).

\section{Pandanus papuanus Solms}

Pandanus papuanus Solms (1883) 93. - Holotype: Beccari s.n. (FI), Indonesia, Maluku, Aru Archipelago, Lutor, June 1873.

Pandanus pistillaris Martelli (1912) 64, t. 40, f. 13-15. - Type: Peekel 209 (FI), Papua New Guinea, Neu Mecklenburg (= New Ireland).

Pandanus pseudopapuanus Martelli (1913) 407, t. 33, f. 1-3. - Type: Lauterbach s.n. (B十; FI), Papua New Guinea, Kaiser-Wilhelmsland.

Pandanus parkinsonii Martelli (1913) 417. - Type: Parkinson s.n. (FI), Papua New Guinea, Bismarck Archipelago, Raoul Island.

Pandanus parkinsonii Martelli var. kukuwae H.St.John (1989) 12, t. 594, 595. - Type: B.C. Stone 2616 (BISH), Papua New Guinea, Bismarck Archipelago, New Britain. Gazelle Peninsula, banks of Keravat River, 14 December 1957.

Pandanus biakensis H.St.John (1960) 231, t. 1a-g, 2-5. - Type: H. St. John 26142 (BISH), Indonesia, Papua, Biak Island, 7 km north of Bosnek, 8 December 1957.

Large solitary tree pandan, 15-20 m high. Prop roots present, obvious, 3-5 m high, spiny, greyish green. Stem hard, spiny, branched, greyish green. Leaves in a rosette, arranged in 3 ranks (tristichous); each lanceolate-elongate, 280-300 cm long, 10-11 cm wide, acuminate apex, margin with spines throughout the length; adaxial surface green, glabrous, venation green, adaxial ventral pleats absent or not seen; abaxial surface pale green, glabrous, main vein obviously spiny, recurved spines absent, basal part yellowish green; leafsheath yellowish green. Infructescence solitary, terminal; peduncle c. $41 \mathrm{~cm}$ long, green to yellowish white. Cephalium massive, heavy, hard, c. $37 \mathrm{~cm}$ long, c. $21 \mathrm{~cm}$ diam (c. $67 \mathrm{~cm}$ circumference), green when young, yellowish green or yellow when old, composed of phalanges. Phalange consisting of 10-11 compacted arranged drupes.

Distribution - Mainland New Guinea, Biak Island, Yapen Island, D'Entrecasteaux Islands, and Bismarck Archipelago.

Habitat - Swamp to lowland tropical rainforests.

Vernacular names - Im (Moluccas, South HalmaheraWeda), Tabaluku (Moluccas, North Halmahera-Galela), Buho (Moluccas, North Halmahera-Tobias), Mandim bepos (Numfor), Waywin (Yapen-Menawi), Andim (Biak), Diem (Kurudu).

Uses - Local people in Yapen Island use the fibres extracted from the prop-roots of $P$. papuanus as source material for making strings, handicrafts (bags), and mats. The cephalium is not eaten. Heyne (1927) reported that $P$. papuanus in Halmahera can only be found in cultivation. Purwanto (2006 pers. comm.) reported that in Halmahera Island the young leaf of a taxon that closely resembles $P$. papuanus is used as a medicine.

Notes - Although in the protologue of $P$. biakensis St. John (1960) stated that the type was made from a tree planted in a forest edge and was said to have been imported from the neighbouring Yapen, prior to this study no collection had been made in Yapen; thus mine confirms this and is to be regarded as a new record.

Specimen seen. IndonesiA, Papua, Yapen Island, South Yapen District, Menawi, 7 Oct. 2006, A.P. Keim 798 (BO!).

\section{Pandanus polycephalus Lam.}

Pandanus polycephalus Lam. (1785) 372. - Pandanus humilis Rumph. (1743) 143, t. 76, nom. inval. - Pandanus humilis Rumph. ex Lour. (1790) 603, quoad synon.; Kurz (1867) 105, t. 63, nom. superfl., non Lour. 1790. - Pandanus kurzianus Solms (1878) 4, nom. superfl. - Type: Pandanus humilis Rumph., Herb. Amboin. 4: t. 76. 1743. - Epitype: Robinson PI. Rumph. Amboin. 54 (holo US; A, BM, BO!, F, K, L, MO, NSW, NY), designated here. Merrill (1917) mentions two collections with the same number: Indonesia, Moluccas, Amboina, Binting and Lateri, in shaded places along streams at low altitudes, or in forests at c. $250 \mathrm{~m}$ alt, July and August 1913.

Jeanneretia littoralis Gaudich. (1843) t. 25, f. 1-7. - Pandanus littoralis (Gaudich.) Kurz (1869) 150. - Type: possibly in P.

Pandanus brevispathus Martelli (1908) 69. - Type: E. B. Copeland 442 (FI; iso NY!), Philippines, Mindanao, Davao, March 1903.

Pandanus aruensis Martelli (1912) 64, nomen; (1914) 419, descr. - Lectotype: Beccari s.n. (FI), designated here, Indonesia, Moluccas, Aru Islands, Wokam ('Vokan') Island, Jabulenga (Giabu-Lenga), March 1873.

Pandanus aruensis Martelli var. contractus Martelli (1912) 64, nom. inval.; (1913) 6, nom. nud. ('contracta'). — Vouchers: Moszkowski 35(B†), Windesi, Van Balen s.n. (FI), no locality, Versteeg s.n. (FI), Indonesia, Papua, Mamberamo, Teba, 21 May 1910.

Pandanus japensis Martelli (1912) 65. — Syntypes: Volkens 421 (B†), Micronesia, Caroline Islands, Yap Island, 1900.

Pandanus aimiriikensis Martelli in Kaneh. (1933) 60, t. 1, photo 1, japonice; (1934) 125, t. 7, latine. - Type: R. Kanehira 328 (FU; iso HUH, NY), Micronesia, Palau (Pelew) Island, Station, main island, Aimeireek Expedition, 10 July 1929.

Pandanus macrojeanneretia Martelli in Kaneh. (1933) 66, japonice; (1934) 121, t. 5, latine. - Type: R. Kanehira 1976 (FU; iso NY), Micronesia, Palau (Pelew) Island, Aimiriik, August 1932.

Pandanus peliliuensis Kaneh. (1935) 113, t. 15, 16. - Type: R. Kanehira \& S. Okamato 2421 (FU; iso NY), Micronesia, Palau Islands, Peliliu Island, August 1933.

Pandanus columniformis Fagerl. (1940) 101, t. 1a-e, 5 a ('columnaeformis'). - Type: F. Fagerlind s.n. (S; iso BO!), origin: Celebes, Pare-Pare, Djompi, 9 September 1912, L. van Vuuren 268, Indonesia, Java, Bogor Botanic Garden, Culta. Bed II A 107 patria Celebes.

Slender clustered tree pandan, 2-5 m high. Prop roots present, slender. Stem slender, branched, greyish green, spiny. Leaves in a rosette, spirally arranged in 3 ranks (tristichous); each lanceolate-elongate, $60-85 \mathrm{~cm}$ long, $2.5-4 \mathrm{~cm}$ wide, acuminate apex, margin with sharp spines throughout the length; adaxial 
surface green, venation green, adaxial ventral pleats absent; abaxial surface pale green, venation green with no spines, recurved spines obvious; leafsheath yellowish white to white. Infructescence in a spike, 30-35 cm long, consisting of 4-7 compactly arranged and sessile cephalia; peduncle $13-18 \mathrm{~cm}$ long, glabrous. Cephalium globose, slightly depressed, $7 \mathrm{~cm}$ long, 4.5-4.8 cm diam (14-15 cm circumference), consisting of numerous drupes. Drupe elongated globose to slightly ellipsoid, green when young turning to bright yellow then to bright reddish orange or red when mature.

Distribution - Celebes, Philippines, Moluccas, New Guinea and adjacent islands including Yapen Island, Bismarck Archipelago, Solomon Islands, and Yap Island in the Caroline Islands (Micronesia).

Habitat - Coastal, beaches, mangrove, and swamps at seaside to few $m$ altitudes.

Vernacular names - Pandan kecil (Moluccas), Berel, Keker or Kekel lainulun, Keker maän (Moluccas-Ambon), Jefe (Moluccas, South Halmahera-Weda), Oro-oro (Moluccas, North Halmahera-Weda), Liliama Dowongi (Moluccas, North HalmaheraTobias), Pandan pantai kecil buah banyak (Malay-Yapen dialect), Benga (Sulawesi-Djompi, Pare-Pare), Denro (Sulawesi, Makassar), Panréng (Sulawesi, Bugis).

Uses - No use of this species has been recorded for Yapen. In the Moluccas the young leaf and bract are used as vegetable and eaten raw (Heyne 1927). The leaves are also used as medicine against food poisoning, especially from seafood (such as fishes and crabs). Leaves mixed with betel nut (Areca catechu) and pepper leaves (Piper betle) are chewed and act as a mild narcotic (Heyne 1927) and also believed as medicine for strengthening the teeth or masticatory (Walter \& Sam 2002). Older leaves are used for mats. Beccari (see Solms-Laubach 1883) reported that the fresh cephalium is used in Sulawesi to cause abortion.

Notes - Warburg (1900b) probably because of the reference to Rumphius and the use of the same epithet treated $P$. humilis Lour. (1790) as a synonym of $P$. polycephalus, but the latter species does not occur in Indochina. Because the citation of Rumphius is too a pre-Linnaean name, Loureiro's name is not necessarily typified by it, and is the correct one for a Indo-Chinese species. Martelli $(1913,1937)$ regarded it as a synonym of $P$. pierrei Martelli, a species native to Cambodia and South Vietnam. It is the other way around: Loureiro's name is the correct one, and P. pierrei is a synonym of it. As Merrill (1917) already wrote: "The type of Loureiro's species is manifestly the Cochinchina plant described, not the Rumphian synonym".

The presence of $P$. polycephalus in Yapen Island is a new record.

Warburg (1900b) assumed that $P$. polycephalus would not be native to the Philippines and that individuals identified as such in the Philippines had actually been introduced, presumably from somewhere in Indonesia (then the Dutch East Indies, most likely from the Bogor Botanic Garden). Merrill (1904) identified two collections made by Copeland from Davao, Mindanao, as $P$. polycephalus. Martelli (1908), however, disagreed and regarded the specimens from Davao as "quite distinct" and to represent an undescribed species, P. brevispathus. Merrill (1922) accepted this.

It would therefore appear that $P$. polycephalus does not occur in the Philippines. However, I have reduced $P$. brevispathus to it, especially because of the similarity of the structure of the infructescences (which was already noted by Martelli himself).

Pandanus aruensis and its variety, $P$. aruensis var. contractus are also treated here as synonyms of $P$. polycephalus because of the structure of the infructescence. The species therefore also occurs in the southern part of the Moluccas. The variety was invalidly published as at the time the species had not yet been described. When that happened (Martelli 1914) the variety was not mentioned.

The presence of $P$. polycephalus as a native of Java has been the subject of debate for a long time. Miquel (1859, sub $P$. humilis) wrote that $P$. polycephalus is native to the Moluccas, and that according to Hasskarl (1845) it would be known in Java as 'Pandan serengseng' and 'Harrassas leutik'. Koorders (1911) mentioned the presence of $P$. polycephalus in Java with a question mark. He believed that the specimens identified by Miquel as $P$. polycephalus actually belonged to either $P$. caricosus Kurz (non Spreng.) or P. atrocarpus Griff. Later he (see also Koorders-Schumacher 1913) identified specimens named 'Pandan serengseng' as such. However, P. atrocarpus has been reported for the Malay Peninsula, Sumatra, Bangka, and Borneo, but has never been found in Java. Backer (1925; see Backer \& Bakhuizen van den Brink Jr. 1968) identified Koorders' $P$. atrocarpus as $P$. caricosus. Regarding $P$. polycephalus in Java Backer (1925) noted "has been erroneously reported for the montane forest of West Java, it might, however here and there grow on the Javanese beach". This is repeated in Backer \& Bakhuizen van den Brink Jr. (1968). The result of this present study indicates that specimens on which Koorders based his record of $P$. atrocarpus in Java (Koorders 20798, 26957, 40265, 40266, and 40267) belong to P. kurzii Merr., a widespread species in Java.

I therefore agree with them and Stone (1972a) that all records in $B O$ and $L$ for Java are based on individuals growing in the Bogor Botanic Garden with various provenances, but none from Java. The most recent exploration made in the Ujung Kulon Nature Reserve in West Java (Keim et al. 2006c) failed to prove the presence of this species.

Solms-Laubach (1883) reported a new species (but did not give it a name because of the absence of male flowers and mature fruits) based on a collection made by Beccari in July 1874 in Lepo-Lepo, Kendari Peninsula, South East Celebes. His description matches $P$. polycephalus, particularly regarding the clumping habit, moderate high stem ( $3-5 \mathrm{~m})$, an infructescence in a spike of 8 red cephalia, each cephalium $5-6 \mathrm{~cm}$ long; thus it is regarded here as belonging to $P$. polycephalus, and thus marks the first record of the species for Celebes.

Fagerlind (1940) described $P$. columniformis on a collection made from a 27 year old individual in the Bogor Botanic Garden believed to be of Celebes origin according to the ledger of acquisitions of the Garden. In BO there is a voucher specimen (Van Vuuren 268) collected by Noerkas (one of the collectors of the Van Vuuren Expedition). Noerkas mentioned that the cephalia were red. Based on the original description, photographs, and the voucher (Table 6 ) this is clearly a synonym.

Pandanus japensis (Table 7) is also a synonym of $P$. polycephalus and a new record of $P$. polycephalus for Yap Island, Micronesia.

Pandanus aimiriikensis and $P$. peliliuensis are also treated here as synonyms of $P$. polycephalus. These two species have many similarities with $P$. polycephalus including the infructescences consisting of 5-8 compactly arranged sessile cephalia and the possession of both terminal and lateral infructescences.

Despite the slightly larger size of the cephalia, P. macrojeanneretia is very much the same as $P$. polycephalus especially because of the 5-8 compactly arranged and aggregated sessile cephalia (Kanehira 1933), thus P. macrojeanneretia is reduced. A lateral infructescence is a distinctive character of $P$. polycephalus as was already observed by Rumphius (1743). 
Table 6 Morphological comparisons on the length and structure of the infructescences, the arrangement of the cephalia, and their colour when mature between Pandanus columniformis and $P$. polycephalus.

\begin{tabular}{|c|c|c|c|c|}
\hline Species & Infructescence structure & Length of infructescence $(\mathrm{cm})$ & $\begin{array}{l}\text { Arrangement of cephalia } \\
\text { per infructescence }\end{array}$ & Colour of cephalia \\
\hline $\begin{array}{l}\text { Pandanus columniformis } \\
\text { P. polycephalus }\end{array}$ & $\begin{array}{l}\text { spike of apparently } 8-10 \text { cephalia } \\
\text { spike of } 4-8 \text { cephalia }\end{array}$ & $\begin{array}{l}\text { c. } 35 \\
30-35\end{array}$ & $\begin{array}{l}\text { compact and sessile } \\
\text { compact and sessile }\end{array}$ & $\begin{array}{l}\text { red } \\
\text { bright yellow turning to red }\end{array}$ \\
\hline
\end{tabular}

Table 7 Morphological comparisons on the infructescence structure, length of the fruiting part of the infructescence, form, length and diam of a cephalium between Pandanus japensis and P. polycephalus.

\begin{tabular}{|c|c|c|c|c|c|}
\hline Species & Infructescence structure & $\begin{array}{l}\text { Length of the fruiting } \\
\text { part of infructescence }(\mathrm{cm})\end{array}$ & Form of cephalium & Length of cephalium $(\mathrm{cm})$ & Diameter of cephalium $(\mathrm{cm})$ \\
\hline Pandanus japensis & $\begin{array}{l}\text { spike of } 6 \text { compactly } \\
\text { arranged sessile cephalia }\end{array}$ & $8-10$ & obscure trigonal & 5 & 4 \\
\hline P. polycephalus & $\begin{array}{l}\text { spike of } 4-8 \text { compactly } \\
\text { arranged sessile cephalia }\end{array}$ & $12-22$ & obscure trigonal & 7 & $4.5-4.8$ \\
\hline
\end{tabular}

The placement of $P$. aimiriikensis, $P$. macrojeanneretia, and $P$. peliliuensis as synonyms has the consequence that $P$. polycephalus is now also found in the Palau Island; thus a new record.

The placement of the numerous species listed above has the biogeographical consequence that the distribution of $P$. polycephalus is recognised here as confined to East Malesia (including Celebes and the Philippines), the Pacific and beyond.

An account made by Hooker (1894) of a possible presence of $P$. polycephalus in Burma is regarded here as pertaining to $P$. foetidus Roxb. This means that $P$. polycephalus does not occur anywhere in mainland South East Asia and thus supports the phytogeographical distribution of the species.

Stone (1966) recorded the presence of $P$. polycephalus in the seashores of Malay Peninsula. However, neither detailed distributional records nor pictures were presented. It is assumed here that Stone might have misidentified $P$. labyrinthicus as $P$. polycephalus. Pandanus labyrinthicus shares a similar habit, some morphological features (including infructescences consisting of 3-8 cephalia), and habitat with P. polycephalus. Indeed, excluding the style in each drupe the two species look very similar. Prior to this study, $P$. labyrinthicus was known only from the west coast of Sumatra (see Warburg 1900b). The presence of $P$. labyrinthicus outside Sumatra is now acknowledged as I have recently re-identified a specimen collected from Tarakan Island, East Kalimantan (Indonesian Borneo, $W$. Meijer 2567) as such; thus a new record. The specimen was previously identified by St. John as $P$. labyrinthicus, but later was misidentified as $P$. nitidus by Stone (he noted: "certe non labyrinthicus") underrating the fact that it is a coastal species with an infructescence consisting of 3 cephalia, in which each drupe has an obvious forked style, a morphological feature that is not possessed by $P$. polycephalus. Pandanus labyrinthicus, on the other hand, does.

Specimens seen. INDONESIA, Papua, Yapen Island, South Yapen District, Randu Ayapé, on the way to Pasir Putih, 5 Oct. 2006, A.P. Keim 790 (BO!); Sarawandori, about 1 hour drive with motorbike west of Serui, 10 Oct. 2006, A.P. Keim 803 (BO!).

\section{Pandanus pseudosyncarpus Kaneh.}

Pandanus pseudosyncarpus Kaneh. (1940) 258. — Holotype: Inokumae 636 (FU), Dutch New Guinea, Nabire, 1940.

Solitary tree pandan, c. $5 \mathrm{~m}$ high. Prop roots present, c. $50 \mathrm{~cm}$ high. Stem unbranched, greyish green, covered with marcescent leaves. Leaves in a rosette, arranged in 3 ranks (tristi- chous); lanceolate-elongate, $360-400 \mathrm{~cm}$ long, $10-11 \mathrm{~cm}$ wide, acuminate apex, margin with obvious spines throughout the length; adaxial surface green, shiny, glabrous, venation green, adaxial ventral pleats obvious; abaxial surface pale green, glaucous white, venation more obvious, main vein with spines, recurved spines obvious, basal part yellow to whitish yellow; leafsheath yellow to whitish yellow. Infructescence a massive spike consisting of 16 condensed cephalia, triangle-shaped, solitary, terminal, c. $23 \mathrm{~cm}$ long, c. $19 \mathrm{~cm}$ diam (c. $60 \mathrm{~cm}$ circumference), bright red, cephalia not uniform in size; peduncle yellowish green, c. $40 \mathrm{~cm}$ long. Cephalium kidney-shaped (reniform), depressed-compressed, bright red, the largest being c. 5 $\mathrm{cm}$ long, c. $11 \mathrm{~cm}$ wide; style pointed, long; stigma pointed.

Distribution - Around Nabire on mainland of Papua, Indonesia (former Dutch New Guinea) and Yapen.

Habitat — Lowland tropical rainforest. In Yapen Island found at foothills at about 100 to $150 \mathrm{~m}$ altitude.

Vernacular name - Pandan buah rambutan (Malay).

Uses - Not recorded.

Note - Prior to the present study P. pseudosyncarpus was known only from a single collection, Inokumae 636 (FU), in a forest near Nabire in 1940 (Kanehira 1940, 1941); thus this finding is a new record.

Specimen seen. INDONESIA, Papua, Yapen Island, South Yapen District, on the road from Saubeba to Konti, eastern side of the island, 11 Oct. 2006, A.P. Keim $810(\mathrm{BO} !)$

\section{Sararanga}

\section{Sararanga sinuosa Hemsl.}

Sararanga sinuosa Hemsl. (1894) 216, t. 11. - Type: Guppy 259 (K), British Solomon Islands, Fauro Island, 1884.

Solitary tree pandan, 9-10 m high. Prop roots absent, roots in general appearance resembling those of the Coconut (Cocos nucifera). Stem unbranched or branched, c. $67 \mathrm{~cm}$ diam. Leaves in a rosette, arranged in 4 ranks, persistent; lanceolate-elongate, c. $300 \mathrm{~cm}$ long, 9-11 cm wide, acuminate apex, margin with spines; adaxial surface glabrous, green to yellowish green, adaxial ventral pleats absent; abaxial surface glabrous, green to yellowish green, recurved spines absent, main vein obvious, with spines; leafsheath yellowish green to cream. Infructescences massive, branched, paniculate (each can weight up to $15 \mathrm{~kg}$ ), terminal, bright green to brownish green; 10 infructescences can be found in 1 individual with branched stem; each branched to 3 orders, glabrous, $150-250 \mathrm{~cm}$ long; peduncle glabrous, c. $50 \mathrm{~cm}$ long, square shaped in cross sec- 
tion; rachis glabrous, $100-200 \mathrm{~cm}$ long; rachillae numerous, glabrous, $36-38 \mathrm{~cm}$ long. Fruits syncarpous, berries c. 100 per rachillae; kidney-shaped (reniform), pale green to red when mature, exocarp soft; seeds c. 60 per berry, triangle-shaped, flat and thin, pale brown.

Distribution - Northern part of mainland New Guinea, Yapen Island, Manus Island, Solomon Islands.

Habitat - Lowland tropical rainforest from sea level up to $200 \mathrm{~m}$ altitude.

Vernacular names - Kayari (Yapen), Sararang (Fauro).

Uses - In Yapen Island the fruits are consumed and the leaves are used for making mats. However, the species is not considered to be an economically important plant, and it is not cultivated. The fruits are reported to be eaten by birds as well.

Notes - The presence of S. sinuosa in Yapen Island was first reported by Beccari when he visited the island between 4-28 April 1875 during his great travels to Celebes and the then Dutch New Guinea. He landed in Ansus, an area within reach of Sarawandori on the western side of the island. Unfortunately, the plant that he saw was not in flower or fruit, thus he could only make a sterile collection (of a leaf, which is still kept in FI). Despite this, he believed without a doubt that the taxon that he saw represented a new genus of Pandanaceae. To satisfy his curiosity he revisited the island from 22 to 23 November in the same year, but failed to improve on his previous collection. Apparently due to the insufficient nature of the collection he refused to publish his finding. Nevertheless, he mentioned his discovery to Solms-Laubach, who then published the information (Solms-Laubach 1883).

12 years later Guppy (1887) found in the Solomon Islands a taxon that he believed was the same as what Beccari saw in Yapen Island. In contrast to Beccari, Guppy managed to obtain a complete (i.e. fertile) collection (Guppy 259). Based on this Hemsley (1894) described Sararanga and appointed it as the type of his $S$. sinuosa. As there has been no complete collection from Yapen after the one by Beccari Hemsley's publication raised the question whether the taxon in Yapen was indeed of the same genus and species. A complete collection of $S$. sinuosa from Yapen (Keim et al. 2006a) has now supported Beccari and ended the 130 years of uncertainty.

Specimen seen. IndonesIA, Papua, Yapen Island, South Yapen District, Sarawandori, about 1 hour drive West of Serui, western side of the island, 10 Oct. 2006, A.P. Keim 800 (BO!).

Acknowledgements The author would like to express his deepest gratitude to Dr. Yohanes Purwanto and Mr. Rio Rovihandono, with whom the author has shared the wonder of Yapen's magnificent tropical rainforest. Appreciations are also sent to Dr. Rugayah, who has given support and suggestions to this paper and to Dr. J.F. Veldkamp (L), who has read this paper and given valuable suggestions on the nomenclature and the typification. In the absence of any Pandanaceae experts Dr. Veldkamp has acted as a good mentor for me. The author would also like to thank the editor of the Flora Malesiana Proceedings for publishing this paper. The exploration has been made possible through a generous support by the Yayasan Keanekaragaman Hayati Indonesia (KEHATI)

\section{REFERENCES}

Backer CA, Bakhuizen van den Brink Jr RC. 1968. Flora of Java 3: 199-206. Noordhoff, Groningen.

Backer CA. 1925. Handboek voor de Flora van Java 1: 36-47. Ruygrok, Batavia.

Balfour IB. 1878. Observations on the genus Pandanus (Screw-Pines). Journal of the Linnean Society, Botany 17: 63.

Blume CL. 1835. Commentationes botanicae imprimis de plantis indiae orientalis. Rumphia 1: 175, 202, t. 53. 1835.

Brongniart AT. 1875. Observations sur les Pandanées de la Nouvelle-Calédonie. Annales des Sciences Naturelles, Botanique VI, 1: 279, t. 14, f. 1.
Fagerlind F. 1940. Vier neue im botanischen Garten von Buitenzorg kultivierte Pandanus Arten. Svensk Botanisk Tidskrif 34, 2: 101, t. 1a-e, 5a.

French BR. 1986. Food plants of Papua New Guinea: A compendium: 158 162. The Australia Pacific Science Foundation, Sheffield-Tasmania.

Gaudichaud-Beaupré C. 1843. Voyage autour du monde ... la Bonite. Botanique: t. 13 , f. $1-8$; t. 20 , f. $1-15$. t. 22 , f. 17 ; t. 25 , f. $1-7$.

Gibbs LS. 1917. Dutch North West New Guinea: A contribution to the phytography and flora of the Arfak Mountains: 198. Taylor, Francis, London.

Guppy HB. 1887. The Solomon Islands, their natives. Swan Sonnenschein, Lowry, Co., London.

Hasskarl JC. 1845. Aanteekeningen over het nut, door de bewoners van Java aan eenige planten van dat eiland toegeschreven: 49. Müller, Amsterdam.

Hemsley R. 1894. A new genus of Pandanaceae. Journal of the Linnean Society, Botany 30: 216, t. 11.

Heyne K. 1927. De nuttige planten van Nederlandsch Indië, ed. 2, 1: 64, 66-67. Departement van Landbouw, Nijverheid en Handel in Nederlandsch Indië, Batavia.

Hooker JD. 1854. Remarks on Doornia and Rykia, two new genera of Screw pines, preceded by some general observations upon that class of plants. Hooker's Journal of Botany and Kew Gardens Miscellany 6: 264.

Hooker JD. 1894. The Flora of British India 6: 487. Reeve \& Co., London.

Hooker JD. 1900. Pandanus cominsii. Hooker's Icones Plantarum: t. 2654.

Huynh K-L. 1976. La morphologie microscopique de la feuille et la taxonomie du genre Pandanus I: Aperçu général sur les charactères micromorphologiques de la feuille du genre Pandanus et leur valeur taxonomique. Botanische Jahrbücher für Systematik, Pflanzengeschichte und Pflanzengeographie 97: 92-93.

Hyndman DC. 1984. Ethnobotany of Wopkaimin Pandanus: Significant Papua New Guinea plant resource. Economic Botany 38, 3: 287-303.

Jebb M. 1992. A field guide to Pandanus in New Guinea, the Bismarck Archipelago, the Solomon Islands: 91. Christensen Research Institute, Madang. Junghuhn FW. 1853. Java, ed. 2, 1: 268. Mieling, 's Gravenhage.

Kanehira R. 1933. Flora Micronesia: 60, t. 1, photo 1; 66, t. 6. Tokyo Imperial University, Tokyo.

Kanehira R. 1934. New or noteworthy trees from Micronesia V. Botanical Magazine (Tokyo) 48: 116-130.

Kanehira R. 1935. New or noteworthy trees from Micronesia X. Botanical Magazine (Tokyo) 49: 113, t. 15, 16.

Kanehira R. 1936. New or noteworthy trees from Micronesia XVII. Botanical Magazine (Tokyo) 50: 544-546.

Kanehira R. 1940. A summary of our knowledge of Papuan Pandanus. Botanical Magazine (Tokyo) 54: 258.

Kanehira R. 1941. The Kanehira-Hatusima 1940 collection of New Guinea plants. 2. Pandanus L. Botanical Magazine (Tokyo) 55: 300-308.

Keim AP, Komara D, Latupapua H, Sulistyo J, Subandi A. 2006b. Flora pandan Wamena, sebagian Lembah Baliem berdasarkan eksplorasi di Kabupaten Jayawijaya, Papua 15-21 Maret 2006: 1-32. Herbarium Bogoriense, Bogor (mimeograph).

Keim AP, Purwanto Y, Rovihandono R. 2006a. Beberapa rekaman baru (new records) dan kemungkinan jenis baru dari suku Pandanaceae di Pulau Yapen, Papua: 1-37. Herbarium Bogoriense, Bogor (mimeograph).

Keim AP, Rugayah, Prawiroatmodjo S, Rahayu M, Windadri F, Sunarti S, Kramadibrata K, Santika Y, Dewi, Sunardi, Hamzah. 2006c. Keanekaragaman suku pandan (Pandanaceae) di beberapa wilayah terpilih dalam lingkup Taman Nasional Ujung Kulon, Banten: 1-29. Herbarium Bogoriense, Bogor (mimeograph).

Koorders SH. 1911. Exkursionsflora von Java 1: 80-81. Monokotyledonen. Fischer, Jena.

Koorders SH. 1913. Exkursionsflora von Java 1. Atlas: 4-8. Fischer, Jena. Koorders-Schumacher A. 1913. Systematisches Verzeichnis der zum Herbar Koorders gehörenden, in Niederländisch-Ostindien, besonders in den Jahren 1888-1903 gesammelten. Phanerogamen und Pteridophyten. I. Abteilung § 1. Java- Phanerogamen. 9. Familie Pandanaceae: 1-4. Selbstverlag der Verfasserin, Buitenzorg (Bogor).

Kunth CS. 1841. Enumeratio plantarum 3: 98. Collae, Stuttgart, Tübingen.

Kurz S. 1867. Revision of the Indian screwpines and their allies. Journal of Botany, British and Foreign 5: 105, t. 63.

Kurz S. 1869. Revision of the Indian screwpines, their allies. Journal of the Asiatic Society of Bengal. Part 2. Natural History 38, 2: 148, 150.

Lamarck JBAP Monnet de. 1785. Encyclopie méthodique. Bontanique 1: 372. Panckoucke, Paris, etc.

Loureiro J. 1790. Flora cochinchinensis: 603. Ulyssipone, Paris.

Martelli U. 1904. Pandani asiatici nuovi. Bollettino della Societa Botanica Italiana: 298-304.

Martelli U. 1905. Pandanus, nuova specie descritte. Webbia 1: 363, 366.

Martelli U. 1908. The Philippine species of Pandanus. Philippine Journal of Science. Section C, Botany 3: 69. 
Martelli U. 1910. Enumerazione delle Pandanaceae. Webbia 3: 307-327.

Martelli U. 1912. Neu Pandanaceae Papuasiens. In: Lauterbach C (ed), Beiträge zur Flora von Papuasien I. Botanische Jahrbücher für Systematik, Pflanzengeschichte und Pflanzengeographie 49: 64-66, t. 40, t. 13-15.

Martelli U. 1913. Enumerazione delle Pandanaceae II. Pandanus. Webbia 4: 6, 407, 417, 419, t. 33, t. 1-3.

Martelli U. 1914. Le specie e varietà nuove di 'Pandanus' menzionate nella 'Enumerazione delle Pandanaceae'. Webbia 4: 399-435, t. 1-43.

Martelli U. 1929. The Pandanaceae collected for the Arnold Arboretum by L.J. Brass in New Guinea. Journal of the Arnold Arboretum 10: 139-140.

Martelli U. 1934. Pandanaceae. In: Kanehira R, New or noteworthy trees from Micronesia V. Botanical Magazine (Tokyo) 48: 116-130.

Martelli U. 1937. Pandanacées. Flore Générale de l'Indo-Chine 6: 1066-1067. Masson \& Cie, Paris.

Merrill ED. 1904. New or noteworthy Philippine plants. Government Laboratory Publication (Philippines) 17: 1-47.

Merrill ED. 1917. An interpretation of Rumphius' Herbarium amboinense. Bureau of Science Publication 9: 82-83.

Merrill ED. 1922. An enumeration of Philippine flowering plants 1: 10-12. Philippine Bureau of Science, Manila.

Merrill ED, Perry LM. 1939. On the Brass collections of Pandanaceae from New Guinea. Journal of the Arnold Arboretum 20: 142-143, 177, 179-180, t. 1, f. 17-18, 20.

Merrill ED, Perry LM. 1940. Plantae papuanae archboldianae, II. Journal of the Arnold Arboretum 21: 163-175.

Miquel FAW. 1851. Analecta botanica indica 2. Verhandelingen der Eerste Klasse van het Koninklijk Nederlandsch Instituut van Wetenschappen, Letterkunde en Schoone Kunsten te Amsterdam III, 3: 29.

Miquel FAW. 1855. Flora van Nederlandsch Indië 3, 1: 159, 161. Van der Post, Amsterdam, etc.

Miquel FAW. 1859. Flora van Nederlandsch Indië 3, 4. Van der Post, Amsterdam, etc.

Peekel PG. 1984. Flora of the Bismarck Archipelago for naturalists: 42. Kristen Press, Madang.

Ridley HN. 1916. Report on the botany of the Wollaston Expedition to Dutch New Guinea. Transactions of the Linnean Society of London, Botany II, 9: 237.

Rumphius GE. 1743. Herbarium amboinense 4: 143-151, t. 76, 79, 80. Franciscus Changuion, Amsterdam, etc.

Schumann K. 1887. Die flora des Deutschen Ost-Asiatischen Schutzgebietes. Botanische Jahrbücher für Systematik, Pflanzengeschichte und Pflanzengeographie 9: 192

Schumann K, Hollrung M. 1889. Die flora von Kaiser Wilhelmsland: 17. Asher \& Co., Berlin.

Solms-Laubach H. 1878. Monographia pandanacearum. Linnaea 42: 4.

Solms-Laubach H. 1883. Über die von Beccari auf seiner Reise nach Celebes und Neu-Guinea gesammelten Pandanaceae. Annales du Jardin Botanique de Buitenzorg 3: 93-94, 96, 100.

Solms-Laubach H. 1889. Pandanus Mac Gregorii F. von Müller. Botanische Zeitung (Berlin) 47: 511

Sprengel KPJ. 1826. Systema vegetabilium 3: 897. Cotta, Stuttgardt.

St John H. 1960. Revision of the genus Pandanus: I. Key to the sections. Pacific Science 14: 231, 239, t. 1a-g, 2-5, 8.
St John H. 1961. Revision of the genus Pandanus. Part 7. New species from Borneo, Papua, and the Solomon Islands. Pacific Science 15: 579.

St John H. 1968. Revision of the genus Pandanus. Part 29. New Papuan species in the section Microstigma collected by C.E. Carr. Pacific Science 22: $515-519$.

St John H. 1973. Revision of the genus Pandanus Stickman. Part 35. Additional Pandanus species from New Guinea. Pacific Science 27: 64, 67, t. $311,312,318,319$

St John H. 1989. Revision of the genus Pandanus, Part 51. Pandanus of the Bismarck and Admiralty Islands: 12, t. 594, 595. St. John, Honolulu.

Stone BC. 1961. The genus Sararanga (Pandanaceae). Brittonia 13: 212 224.

Stone BC. 1965. Melanesian plant studies I. With Micronesian supplement: 1-6. University of Malaya, Kuala Lumpur.

Stone BC. 1966. Pandanus Stickm. in the Malayan Peninsula, Singapore, and Lower Thailand. Malayan Nature Journal 19, 5: 291-301.

Stone BC. 1967. Notes on the plant genus Pandanus in Fiji, Tonga, the New Hebrides, and Niue. Proceedings of the Biological Society of Washington 80: 47-60.

Stone BC. 1968. Materials for a monograph of Freycinetia Gaud. IV. Subdivision of the genus with fifteen new sections. Blumea 16: 361-372.

Stone BC. 1969. Materials for a monograph of Freycinetia Gaud. X. Chronological list of all binomials. Taxon 18: 672-680.

Stone BC. 1972a. Studies in Malesian Pandanaceae: VII. A review of Javanese Pandanaceae with notes on plants cultivated in the Hortus Botanicus Bogoriensis. Reinwardtia 8, 2: 309-318.

Stone BC. 1972b. The genus Pandanus in the Solomon Islands with notes on adjacent regions. Part 1. Malaysian Journal of Science 1 (A): 109.

Stone BC. 1974 (26 March). Studies in Malesian Pandanaceae XIII. New and noteworthy Pandanaceae from Papuasia. Contributions from Herbarium Australiense 4: 23, f. 9-11.

Stone BC. 1975a. Pandanaceae of Ceylon. Ceylon Journal of Science. Biological Sciences 11, 2: 118.

Stone BC. 1975b. The Pandanaceae of the New Hebrides with an essay on intraspecific variation in Pandanus tectorius. Kew Bulletin 31: 50.

Stone BC. 1982. New Guinea Pandanaceae: First approach to ecology and biogeography. In: Gressitt JL (ed), Biogeography and ecology of New Guinea. 1. Monographiae Biologicae 42: 401-436.

Stone BC. 1987. New taxa of Pandanus (Pandanaceae) from Malesia and Papuasia. Blumea 32: 435, f. 5.

Stone BC. 1992. The New Guinea species of Pandanus section Maysops St. John (Pandanaceae). Blumea 37: 31-61.

Vieillard E. 1861. Plantes utiles de la Nouvelle-Calédonie. Annales des Sciences Naturelles, Botanique IV, 16: 51.

Walter A, Sam C. 2002. Fruits of Oceania. Australian Centre for International Agricultural Research (ACIAR) Monograph 85. Canberra.

Warburg O. 1900a. (1 Oct.) Pandanaceae. In: Schumann K, Lauterbach K, Flora der deutschen Schutzgebiete in der Südsee: 159, 161. Gebrüder Borntraeger, Leipzig.

Warburg O. 1900b. (21 Dec.). Pandanaceae. In: Engler HGA, Das Pflanzenreich IV, 9: 30, 49, 71, 83, 84. Engelmann, Berlin.

Warburg O. 1905. Freycinetia streptopifolia. In: Schumann K, Lauterbach K, Nachträge zur Flora der deutschen Schutzgebiete in der Südsee: 53. Gebrüder Borntraeger, Leipzig. 